\title{
Effect of Competence, Information Systems Management, Organizational Culture on the Job Satisfaction, Organizational Commitment and Teacher Performance
}

\author{
*Jayady Yahya ${ }^{1}$, H. Syahnur Said ${ }^{2}$, H. Muh. Nasir $\operatorname{Hamzah}^{3}$, Hamza Ella $^{4}$ \\ ${ }^{1)}$ Doctoral Student in the Faculty of Economics, University of Muslim Indonesia \\ ${ }^{2,3,4)}$ Faculty of Economics, University of Muslim Indonesia \\ Corresponding Author: *Jayady Yahya
}

\begin{abstract}
The purpose of this study was to analyze the effect of competence, information systems management and organizational culture on job satisfaction, organizational commitment and performance of teachers, to analyze the impact of job satisfaction on the performance of teachers, to analyze the effect of organizational commitment on teacher performance, to analyze the effect of competence through job satisfaction on teacher performance, to analyze the effect of information management system through job satisfaction and organizational commitment on teacher performance, and to analyze the effect of organizational culture through the organization's commitment on teacher performance. The research was conducted on 10 private junior high school and 10 public junior high school namely SMP in Makassar City with a population of 909 teacher and a sample set with Slovin formula as many as 278 teacher. The data from questionnaires were analyzed using Structural Equation Model using AMOS assistance 18. The study found that direct information management system is a positive and insignificant effect on job satisfaction, organizational commitment and teachers' performance. This means that the information management system application has been run by the teachers, but the information management system application did not show significant correlation (insignificant) against the teacher job satisfaction, organizational commitment and teacher performance. Indirectly effect has found that the information management system through organizational commitment is a positive and insignificant effect on teachers' performance. This means that teachers have to understand and know the importance of a series of activities of input, process, output and feedback in the application license, so it has a positive effect, but its application was not significantly correlated on job satisfaction and organizational commitment, because the application of the information management system oriented utilization and use of schools media and are not real anyway directly correlated on teachers performance.
\end{abstract}

Keywords: Competence, information management, culture, satisfaction, commitment, teacher performance

\section{Introduction}

Department of National Education in this case the education office of Makassar in implementing the national education system, need to assess in particular the achievement of the performance of teachers, including in this case the teacher of junior high school (SMP) both of public and private school. Basis to make this assessment refers to Law No. 14 Year 2005 on Teachers and Lecturers. This law is a binding regulation that teachers are professionals who are required to have a high performance in organizing the learning process in schools. On this basis the Indonesian Department of Elementary and Secondary Education received reports and information that the teacher performance of junior high school in the city of Makassar is still low. Various causes decreased performance of teachers including in this case which enables influencing this decline include the competence of teachers, information management systems, organizational culture in the school environment, job satisfaction and organizational commitment to the cause of teacher performance decreases. These causes need to be observed carefully by the phenomena, facts and data in the dynamics of school organization and the presence of the teacher.

Upon consideration of this, the researchers had the initiative to do the preliminary observations in scrutinizing the causes of the teachers performance of in Makassar declined. Based on field observations, researchers found there was a gap between expectations and reality. Junior high school teacher in Makassar showed low performance. This phenomenon is visible from most of junior high school teacher both public and private are less able to develop a Plan Preparation Learning (PPL), the level of ability of mastering the material of teachers is still low, there are many teachers who did not master the methods and strategies to learn well, the 
frequency of the administration tasks to students who lack, lack of management students, as well as the less provide an objective assessment and evaluation, this is what caused the teacher's performance declined.

The decline in performance can be seen from the non-optimal potential possessed by a teacher in producing the work in accordance with the performance appraisal. Has a fond of partially teachers do not undertake manufacture (PPL), which causes learning plan owned less, there are teachers that level of mastery of the work that is not in accordance with the performance standards expected, the level of methods and strategy for the control of work that is still lacking in developing learning, the level of giving assignment to a student who is still less applied properly, the ability of students who have not integrated management in improving job performance, as well as the assessment and evaluation of teachers' work has not been standardized achievement oriented optimal results in its development. As a result of the performance of teachers is low cannot be separated from the influence of teacher competence is still low in the potential development of education and teaching, the low utilization and the use of information management systems (IMS) in the development of teaching and learning, is not structured of organizational culture that is constructive in developing the existence of teachers conduct education and teaching, as well as low levels of job satisfaction of teachers in the face of the teaching field to which it aspires and organizational commitment that a teacher has not been pledged by both in developing tasks in the field of education and teaching led to the teacher's performance declined.

The following data show the percentage of teacher performance of junior high school in Makassar, which is registered at the Department of National Education (education Office) of Makassar Year 2010 - 2014 in Table 1 below:

Table 1. The percentage of teacher's performance of junior high school in Makassar

\begin{tabular}{|c|c|c|c|c|c|c|}
\hline \multirow{2}{*}{ Years } & \multicolumn{5}{|c|}{ Teacher's performance (\%) } & \multirow{2}{*}{ Average } \\
\cline { 2 - 6 } & Teaching & quality & $\begin{array}{c}\text { teaching } \\
\text { time }\end{array}$ & material & presence & \\
\hline 2012 & 83.4 & 75.9 & 84.6 & 82.4 & 80.7 & 81.40 \\
\hline 2013 & 82.4 & 73.8 & 83.4 & 80.2 & 80.2 & 80.00 \\
\hline 2014 & 80.2 & 71.9 & 83.9 & 71.9 & 78.5 & 77.28 \\
\hline 2015 & 76.4 & 70.5 & 82.7 & 70.5 & 77.9 & 75.60 \\
\hline 2016 & 75.6 & 68.3 & 79.5 & 68.3 & 76.4 & 73.62 \\
\hline
\end{tabular}

The table 1 shows above the percentage of teacher performance appraisal in Makassar for the five-year average decline seen from the number of teaching, the quality of teaching methods, teaching hours, teaching materials and teacher attendance. In 2012, the average percentage of the performance of junior high school teacher in the city of Makassar declined by $81.40 \%$ up to $73.62 \%$ in 2016 . This means that the number of teaching in quantity can be improved by frequently giving at least 18 sessions of teaching, the quality of teaching methods need to be updated to be easily absorbed by students, teaching hours proper time efficiently be applied, effective teaching materials need to be improved to facilitate the students receive lessons and loyalty rate teachers in teaching should be improved in each attendance teaches.

The phenomenon of declining on several teacher performance in Makassar both public and private junior high school gives an indication of the decline in student achievement on formative assessment and summative assessment in a school year based on assessment of teaching and learning in schools. In connection with the above data that indicate that teacher performance into consideration in the learning process. Efforts to improve the performance of teachers need to apply the standard theory of teacher performance by Sahertian (2009: 49) that the standards of teacher performance is related to the quality of teachers in performing their duties such as: (1) the ability to make the planning and preparation of teaching, (2) mastery of the material to be taught to students, (3) mastery of teaching methods and strategies, (4) assignments to students, (5) the ability to manage students, and (6) the ability to make an assessment and evaluation.

The decline in teacher performance can be caused by various things related to non-fulfillment of job satisfaction and organizational commitment. Arreto (2009: 45) states that job satisfaction and organizational commitment directly affect a person's performance. Teachers who fulfilled job satisfaction and organizational commitment has always had a strong positive influence and significant increase in performance. Conversely, if the job satisfaction and organizational commitment is not met or low it can be a negative and in significant effect. It has associated with the performance of junior high school teacher in the city of Makassar, to be indicated that causes performance drops due to teacher job satisfaction and organizational commitment is low. Visible teacher job satisfaction on the job learning process that occupied less than satisfactory and influence organizational commitment of teachers is low. Due to unsatisfactory job satisfaction and organizational commitment are low to give effect to a decrease in the teachers' performance.

A teacher who is not satisfied with his work in teaching and learning encounters, usually show a dissatisfied manner to face the challenges of the job, is not satisfied with the progress of work achieved, not 
satisfied with the achievements that do not boast, it is not satisfied with the creativity of the work that has been commonly used and is not satisfied because it is not interested in the work that is monotonous. As a result of the teacher is not satisfied with the work done, this affects organizational commitment of teachers in schools where teaching. Usually forms of organizational commitment shown teachers tend to show reluctance in promoting school(affective), do not have a commitment to abide by the school rules(normative),there is a commitment to making school perform(continue)and do not have a commitment to focus on achieving school goals(perspective). Low levels of job satisfaction and organizational commitment is directly influence teacher performance decline.

The effect of job satisfaction and organizational commitment on performance can be realized by applying the embodiment of the theory of job satisfaction (satisfied actualization work theory). The theory of job satisfaction proposed embodiment Hersey (2007: 47) that job satisfaction can be realized and unrealized depend on people working and employment generated. Embodiments of job satisfaction, satisfied or not, is determined by the challenges of work, work progress, achievement, creativity generated and perceptions about the work itself is interesting or not. Job satisfaction is an impact for a person to increase their commitment to the organization and improve its performance. This is supported by several previous relevant studies include research Ayesha (2013) with the results of employee satisfaction on the performance. Job satisfaction is determined by the job and career that has that increases job satisfaction. Further research by Chamdan Purnama (2013) which shows the results of research that job satisfaction affects the performance. While the influence of organizational commitment on performance improvement can be made by applying the theory pioneered pledge commitments totality Smith \& Meyer (2009: 155) that organizational commitment is a pledge totality of a person's behavior in carrying out its activities to achieve organizational goals. The totality of a person's behavior pledge embodied in commitment, affective normative, continue and perspective. Affective commitment is a pledge to promote the organization, normative is a pledge to abide by the rules of the organization, continuous is continuous and perspectives pledge is a pledge to organizational objectives. This theory gives effect for a person to have a strong organizational commitment to improve its performance.

Previous research that supports that organization's commitment to give effect to the performance that the researcher by Alam (2014) the research showed that increased performance is determined by the applied organizational commitment of employees. In addition by Chamdan Purnama (2013) the visible commitment is a positive and significant effect on performance. It shows that the achievement of performance is determined by the commitment of the organization to carry out any procedures that apply in the organization. Understanding the description set forth above, it is known that job satisfaction, organizational commitment and performance of junior high school teachers in the city of Makassar is low is directly influenced by the competency of teachers, implementation of management information systems is not optimal and organizational culture that has not done well, so affect the level of job satisfaction and organizational commitment to the low performance of teachers in the teaching and learning process in schools.

According to Ward (2010: 66) when the person is not enhanced competence, information management systems are not applied optimally and organizational culture is not structured, directly or indirectly affecting low job satisfaction and organizational commitment declined to the improved performance. This can be seen in the fact as a phenomenon that shows the influence of the variable competence, management information systems and organizational culture in influencing job satisfaction and organizational commitment to the improvement of teacher performance. The phenomenon of competence on job satisfaction, organizational commitment and performance of teachers showed that teachers in carrying out their teaching duties not all are able to develop their competence both in pedagogic in carrying the knowledge that can be adopted by the students, the ability of teaching methods that have not been professional, behavioral and personality traits of teachers still less as well as social interaction in socializing with the school environment needs to be improved. The shape of the competency of teachers is still low certainly influence directly and indirectly to job satisfaction, organizational commitment and performance of teachers.

Teacher competence is still low on job satisfaction, organizational commitment and performance can use the theory of self competence. This theory proposed by Albert (2010:13) that the competence of a person can be known from pedagogic ability, professional, personal and social. Pedagogic ability reflected insight knowledge, professional ability is reflected in the work methods or techniques used, the ability of personality can be seen from the character and behavior in work and social skills can be seen from social interaction and cooperation undertaken by someone. This view into a view that needs to be actualized by a teacher to correct or improve competences that influence job satisfaction, organizational commitment and performance improved.

The previous studies support the positive and negative are significant or insignificant effects that the competence effect on job satisfaction backed previous investigators by Chamdan Purnama (2013); Amin Akhavan (2009); Erick W. (2010) demonstrated competence influence on organizational commitment, as well as study results by Alam (2014), which examines the competence to organizational commitment and performance. In general it can be concluded that the competence to give positive and significant impact on job satisfaction, 
organizational commitment and performance, if the competence of a person at increased. Instead of competence can negatively impact and insignificant, if someone has decreased competence. Another fact also shows there is a phenomenon that the implementation of information management systems (IMS) in several junior high schools in Makassar has not been implemented optimally by each teacher in the school in the process of effective teaching and learning. IMS is not optimal application of an impact on job satisfaction, organizational commitment and low performance. IMS is not optimal application of, among others, viewed from the input, process, output and feedback on the implementation of this system that has not been implementation well in making school-based systems and technology.

Application of information management systems is not optimal views of inputs such as database activity subjects, list of teachers, students are taught the class, teacher and student attendance, student achievement every class and others who have not been in the input. Activities process that has not handled optimally subjects such as process scheduling, summative and formative exam, the student exam results and others that process is still slow and often incorrect. Activity output has not given the best results as the learning process is less smooth, irregular teaching schedule and underachieving students. Activity is still difficult actionable feedback that is still declining student achievement, teachers' teaching quality is low and declining school rankings. IMS is not optimal application of an impact on job satisfaction, organizational commitment and performance of teachers. Effect of information management systems on job satisfaction, organizational commitment and performance could use an information management systems application theory of Davis (2010: 41) that the success of an organization is determined from the IMS application (information management systems). IMS application includes a series of activities starting from the input, process, output and feedback. Input the IMS application is all the activity data and information entered in the computerized system. Process in the IMS application is processed activities in a computerized management. Output in the IMS application is the result of the activity of computerized management process. Feedback in the IMS application is a follow-up of input, process and output of the application of computerized management.

No previous studies support the positive and negative effects are significant or not significant that the IMS effect on job satisfaction backed previous investigators by Shehade \& Nazem (2013); Fawsi Hasan Altanny (2013) showing that there are positive and significant effect of the adoption of IMS effect on satisfaction, commitment and performance if they are not applied. Likewise, the phenomenon of organizational culture in fact has not been implemented properly, especially with regard to the implementation of organizational culture seen from of the mission schools were not realized, the inconsistency of teachers in performing their duties and obligations, unable to adapt to the changing demands of dynamic organization and the low level of teacher involvement in advancing education. Poor understanding of the organizational culture of the teacher related to the mission, consistency, adaptability and engagement in the learning process gives low influence job satisfaction, organizational commitment and performance of teachers.

The low culture of organizations that implemented by teachers in carrying out their work activities, seen most of the teachers do not understand the importance of the mission of the school in which to teach, so it looks inconsistent behavior in carrying out his duties as a teacher has a teaching profession to be able to adapt to the demands and needs of changing the dynamics of the organization wants the involvement of teachers optimally, but in fact among teachers who feel less proud of the profession bears, which causes rarely involved in the advancement of education in junior high school. The influence of organizational culture on job satisfaction, organizational commitment and performance can use the theory of the essence of the organizational culture. This theory was put forward by Dannis (2010: 55) that the essence of organizational culture is built on four pillars: the essence of the mission, consistency, adaptability and engagement. Fourth essence that's a strong adhesive that brings progress and achievement of organizational goals. This theory is relevant to use that application of organizational culture implemented in schools influence on job satisfaction, organizational commitment and teacher's performance.

It is relevant to a study conducted researchers by Chamdan Purnama (2013); Joo Jung \& Xuemei Su (2008); John Meyer (2010); Eric W. (2010), with the results generally show a positive organizational culture provides meaningful significant on job satisfaction, the negative and significant effect of organizational culture on organizational commitment, and a positive and significant effect on organizational culture but does not significantly affect on teachers performance. In general, the organizational culture is a positive and a significant effect on job satisfaction, organizational commitment and individual performance, if the organizational has increased. Instead of organizational culture can negatively impact and no significant effect on satisfaction, commitment and performance organizational culture if has decreased.

\section{Competence}

\section{Literature Review And Hypothesis Testing}

Competence refers to the theory of self competency was pioneered by Albert (2010:13) that the competence of a person can be known from pedagogic ability, professional, personal and social. 
$\mathrm{H}^{\text {1a }} \quad$ Competence is a positive and significant effect on teacher's job satisfaction

$\mathrm{H}^{1 \mathrm{~b}} \quad$ Competence is a positive and significant effect on organizational commitment

$\mathrm{H}^{1 \mathrm{c}} \quad$ Competence is a positive and significant effect on teacher's performance

$\mathrm{H}^{1 \mathrm{~d}} \quad$ Competence is a positive and significant effect on teacher's performance through job satisfaction

$\mathrm{H}^{1 \mathrm{e}} \quad$ Competence is a positive and significant effect on teacher's performance through organizational commitment

\section{Information management system}

Information management system (IMS) using the application of Information management theory of Davis (2010: 41) that the success of an organization is determined from the IMS application. IMS application includes a series of activities starting from the input, process, output and feedback.

$\mathrm{H}^{2 \mathrm{a}}$ Information management system is a positive and significant effect on job satisfaction

$\mathrm{H}^{2 \mathrm{~b}}$ Information management system is a positive and significant effect on organizational commitment.

$\mathrm{H}^{2 \mathrm{c}}$ Information management system is a positive and significant effect on teacher's performance

$\mathrm{H}^{2 \mathrm{~d}}$ Information management system is a positive and significant effect on teacher's performance through job satisfaction.

$\mathrm{H}^{2 \mathrm{e}}$ Information management system is a positive and significant effect on teacher's performance through organizational commitment

\section{Organizational Culture}

Organizational culture refers to the essence of the theory of organizational culture. This theory was put forward by Dannis (2010: 55) that the essence of organizational culture is built on four pillars: the essence of the mission, consistency, adaptability and engagement. Fourth essence that's a strong adhesive that brings progress and achievement of organizational goals.

$\mathrm{H}^{3 \mathrm{a}}$ Organizational culture is a positive and significant effect on job satisfaction

$\mathrm{H}^{3 \mathrm{~b}}$ Organizational culture is a positive and significant effect on organizational commitment

$\mathrm{H}^{3 \mathrm{c}}$ Organizational culture is a positive and significant effect on teacher's performance

\section{Job Satisfaction}

Job satisfaction refers to the embodiment of the theory of job satisfaction (satisfied actualization work theory). The theory of job satisfaction pioneered embodiment Hersey (2007: 47) that job satisfaction can be realized and unrealized depend on people working and employment generated.

$\mathrm{H}^{4}$ Organizational culture is a positive and significant effect on teacher's performance through job satisfaction

\section{Organizational Commitment}

Organizational commitment refers to the totality of commitment theory pioneered pledge Smith \& Meyer (2009: 155) that organizational commitment is a pledge totality of a person's behavior in carrying out its activities to achieve organizational goals.

$\mathrm{H}^{5}$ Organizational culture is a positive and significant effect on teacher's performance through organizational commitment

\section{Teacher Performance}

Performance as a variable of interest (ending variable) refers to the standard theory of teacher performance developed by Sahertian (2009: 49) that the standards of teacher performance is related to the quality of teachers in performing their duties views of the ability to make the planning and preparation of teaching, mastery of the material to be taught to students, mastery of teaching methods and strategies, assignments to the students, the ability to manage students, and the ability to make an assessment and evaluation.

$\mathrm{H}^{6 \mathrm{a}}$ Job satisfaction is a positive and significant effect on teacher's performance

$\mathrm{H}^{6 \mathrm{~b}}$ Organizational commitment is a positive and significant effect on teacher's performance

\section{Methods}

This study was designed to address problems that have been formulated and the goals to be achieved and to test the hypothesis. Location of research carried out on environmental Junior School in Department of Education Makassar City as an object of research to see the effect of competence, management information systems, organizational culture on job satisfaction, organizational commitment and performance of junior high 
school teachers in the city of Makassar. The study is beginning in March until June 2017. There are two type of research is quantitative and qualitative research. Sources of data in this study consisted of primary and secondary data. Data collection techniques (instruments) are observation, questionnaires, interviews and documentation. The population in this study is all teachers who work in 10 private junior high school and 10 public junior high school. The population in this studies as many as 909 teachers. A sample is a collection of selected sampling units from a sampling frame. The Slovin formula obtained using 278 teachers (sample respondents). Data analysis techniques used in explaining the phenomenon in this research is descriptive statistical analysis techniques and analysis of Structural Equation Modeling (SEM).

\section{Discussion}

This first model testing variables grouped into exogenous variables and endogenous variables. Exogenous variables are a variable whose value is determined outside the model. While the endogenous variable is a variable whose value is determined by an equation or model relationship is formed. Included in this group of exogenous variables is the measurement of competence, IMS and organizational culture, while those classified as an endogenous variable is job satisfaction, organizational commitment and performance of teachers. The model is said to be good when the development of theoretically hypothetical model supported by empirical data. The results of SEM analysis are complete can be seen in the following figure:

Figure 1 First Model

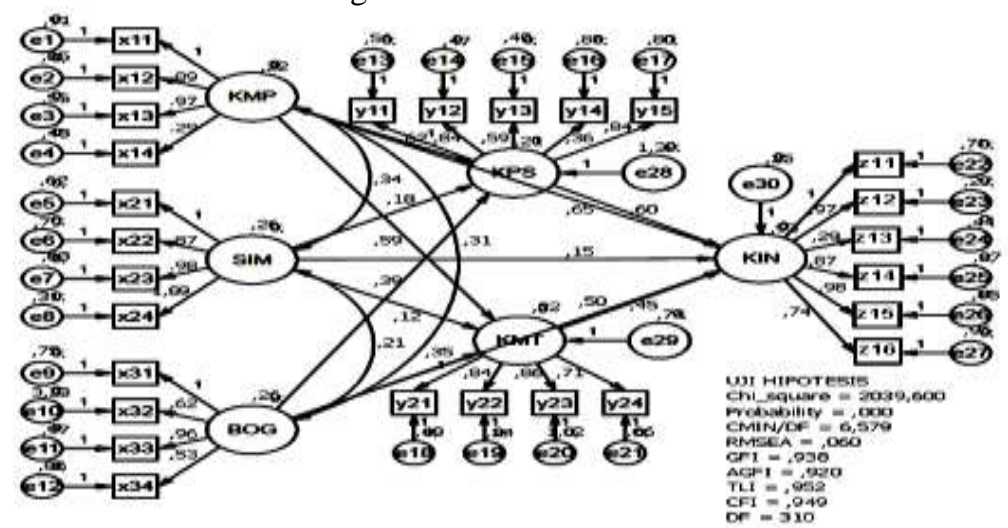

Based on the evaluation models suggest eight criteria of goodness of fit indices seen chi-square value is still large and seen some of the criteria are not in accordance with the cut off determined, so that a modification of the model by performing the correlation between the error indicator according to the instructions of the modification indices. The results of the analysis after the final model obtained are as follows:

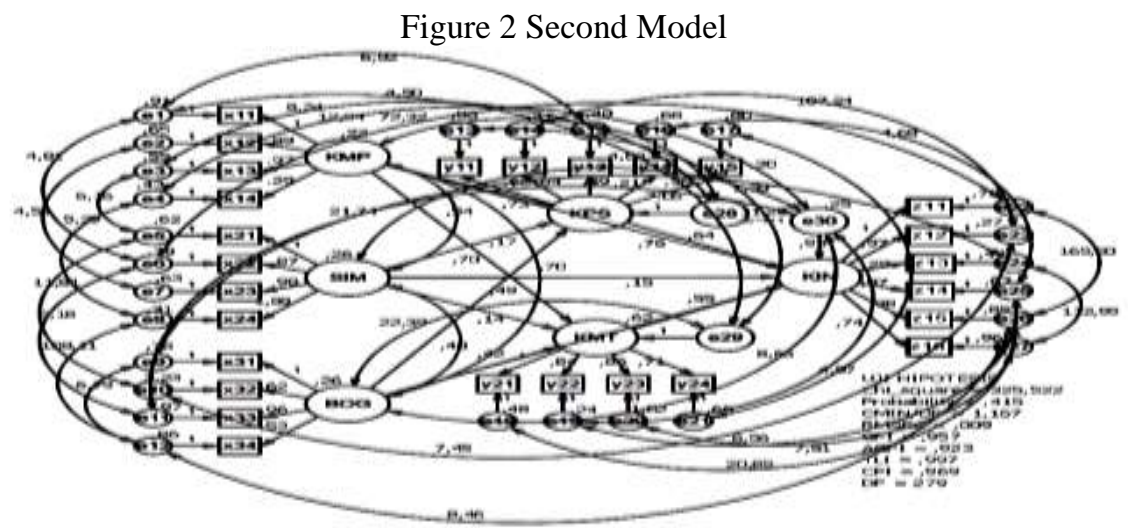

The model test results are presented in Figure 2 are evaluated based on the goodness of fit indices are presented in Table 2 with the criteria of the model as well as critical values that have compatibility data. 
Effect of competence, information systems management, organizational culture .....

Table 2 Goodness of fit indices second model

\begin{tabular}{|c|c|c|c|c|c|}
\hline $\begin{array}{l}\text { Goodness of } \\
\text { fit index }\end{array}$ & Cut-off Value & First Model & annotation & Second Model & annotation \\
\hline Chi-square & small & 2039,600 & Marginal & 325,522 & Good \\
\hline Probability & $\geq 0,05$ & 0,000 & Marginal & 0,415 & Good \\
\hline CMIN / DF & $\leq 2,00$ & 6,579 & Marginal & 1,167 & Good \\
\hline RMSEA & $\leq 0,08$ & 0,060 & Marginal & 0,009 & Good \\
\hline GFI & $\geq 0,90$ & 0,938 & Good & 0,957 & Good \\
\hline AGFI & $\geq 0,90$ & 0,920 & Good & 0,923 & Good \\
\hline TLI & $\geq 0,94$ & 0,952 & Good & 0,997 & Good \\
\hline $\mathrm{CFI}$ & $\geq 0,94$ & 0,949 & Good & 0,969 & Good \\
\hline \multicolumn{2}{|c|}{$\mathrm{DF}$} & 310 & & 279 & \\
\hline
\end{tabular}

The results of the evaluation model for early stage shows of the eight criteria of goodness of fit indices there are four that have met the criteria cut-off value, likes, GFI, AGFI, TLI and CFI, so it needs to be modified in accordance with the instructions of the model modification indices. Modification Indices (MI) is a calculation to make changes to the figures, where the figures below indicate substantial minimum value chi-square will go down if the corresponding variable is connected. After the modification of the model, then the final stage of the eight criteria indicate the goodness of fit indices have met the criteria or the appropriate cut-off value, so the model is said to have been in accordance with the criteria of goodness of fit indices for analysis.

Based on empirical models proposed in this study can be tested against the hypothesis put forward by testing the path coefficients in structural equation modeling. Table2, is a test of hypothesis by looking at the value of $p$-value, if the $p$-value $<0.05$ then a significant relationship between the variables. It also describes the direct effect means that there are positive directly between variables, the indirect effect means that there are positive influence indirectly between variables, and the total effect is the accumulation of direct influence and indirectly. The test results are presented in the following the table:

Table 3 Hypothesis testing

\begin{tabular}{|c|c|c|c|c|c|c|c|}
\hline \multirow{2}{*}{ exogenous variables } & \multirow{2}{*}{\multicolumn{2}{|c|}{ endogenous variables }} & \multicolumn{5}{|c|}{ Standardized Regression } \\
\hline & & & p-value & direct & indirect & Total & annotation \\
\hline Competence $\left(\mathrm{X}_{1}\right)$ & \multicolumn{2}{|c|}{ Job satisfaction (Y1) } & 0,000 & 0,712 & - & 0,712 & significant \\
\hline $\operatorname{IMS}\left(\mathrm{X}_{2}\right)$ & \multicolumn{2}{|c|}{ Job satisfaction $\left(\mathrm{Y}_{1}\right)$} & 0,089 & 0,139 & - & 0,139 & Insignificant \\
\hline Org. Culture $\left(\mathrm{X}_{3}\right)$ & \multicolumn{2}{|c|}{ Job satisfaction $\left(\mathrm{Y}_{1}\right)$} & 0,010 & 0,412 & - & 0,412 & Significant \\
\hline Competence $\left(\mathrm{X}_{1}\right)$ & \multicolumn{2}{|c|}{ Org. Commitment $\left(\mathrm{Y}_{2}\right)$} & 0,003 & 0,658 & - & 0,658 & Significant \\
\hline IMS $\left(\mathrm{X}_{2}\right)$ & \multicolumn{2}{|c|}{ Org. Commitment $\left(\mathrm{Y}_{2}\right)$} & 0,165 & 0,157 & - & 0,157 & Insignificant \\
\hline Org. Culture $\left(\mathrm{X}_{3}\right)$ & \multicolumn{2}{|c|}{ Org. Commitment $\left(\mathrm{Y}_{2}\right)$} & 0,022 & 0,428 & - & 0,428 & Significant \\
\hline Competence $\left(\mathrm{X}_{1}\right)$ & \multicolumn{2}{|c|}{ Teacher performance $(Z)$} & 0,000 & 0,694 & - & 0,694 & Significant \\
\hline $\operatorname{IMS}\left(\mathrm{X}_{2}\right)$ & \multicolumn{2}{|c|}{ Teacher performance $(\mathrm{Z})$} & 0,185 & 0,161 & - & 0,161 & Insignificant \\
\hline Org. Culture $\left(\mathrm{X}_{3}\right)$ & \multicolumn{2}{|c|}{ Teacher performance $(\mathrm{Z})$} & 0,000 & 0,591 & - & 0,591 & Significant \\
\hline Job satisfaction $\left(\mathrm{Y}_{1}\right)$ & \multicolumn{2}{|c|}{ Teacher performance $(\mathrm{Z})$} & 0,000 & 0,671 & - & 0,671 & Significant \\
\hline $\begin{array}{c}\text { Org. Commitment }\left(\mathrm{Y}_{2}\right) \\
\text { exogenous }\end{array}$ & \multicolumn{2}{|c|}{ Teacher Performance $(\mathrm{Z})$} & 0,000 & 0,584 & - & 0,584 & Significant \\
\hline exogenous & intervening & endogenous & $\mathrm{p}$-value & direct & indirect & Total & annotation \\
\hline Competence $\left(\mathrm{X}_{1}\right)$ & $\begin{array}{c}\text { Job satisfaction } \\
\left(\mathrm{Y}_{1}\right)\end{array}$ & $\begin{array}{c}\text { Teacher performance } \\
(\mathrm{Z})\end{array}$ & 0,000 & 0,694 & 0,281 & 0,975 & Significant \\
\hline $\operatorname{IMS}\left(\mathrm{X}_{2}\right)$ & $\begin{array}{l}\text { Job satisfaction } \\
\left(\mathrm{Y}_{1}\right)\end{array}$ & $\begin{array}{c}\text { Teacher performance } \\
(\mathrm{Z})\end{array}$ & 0,624 & 0,161 & 0,087 & 0,248 & Insignificant \\
\hline Org. Culture $\left(\mathrm{X}_{3}\right)$ & $\begin{array}{c}\text { Job satisfaction } \\
\left(\mathrm{Y}_{1}\right)\end{array}$ & $\begin{array}{c}\text { Teacher performance } \\
(\mathrm{Z})\end{array}$ & 0,000 & 0,591 & 0,266 & 0,857 & Significant \\
\hline Competence $\left(\mathrm{X}_{1}\right)$ & $\begin{array}{l}\text { Org. Commitment } \\
\qquad\left(\mathrm{Y}_{2}\right)\end{array}$ & $\begin{array}{c}\text { Teacher performance } \\
\text { (Z) }\end{array}$ & 0,000 & 0,694 & 0,281 & 0,975 & Significant \\
\hline $\operatorname{IMS}\left(\mathrm{X}_{2}\right)$ & $\begin{array}{l}\text { Org. Commitment } \\
\left(\mathrm{Y}_{2}\right)\end{array}$ & $\begin{array}{l}\text { Teacher performance } \\
\text { (Z) }\end{array}$ & 0,624 & 0,161 & 0,087 & 0,248 & Insignificant \\
\hline Org. Culture $\left(\mathrm{X}_{3}\right)$ & $\begin{array}{l}\text { Org. Commitment } \\
\left(\mathrm{Y}_{2}\right)\end{array}$ & $\begin{array}{c}\text { Teacher performance } \\
(\mathrm{Z})\end{array}$ & 0,000 & 0,591 & 0,266 & 0,857 & Significant \\
\hline
\end{tabular}

From the second model of eleven straight lines and three indirect pathways hypothesized, seen eight straight lines give a positive and significant effect, while three direct paths provide a positive influence and not significant. For the indirect effect, visible one path positive indirect and insignificant, and there are two paths indirect positive and significant. The interpretation of Table 3 can be explained as follows:

Competence has a direct influence positive and significant impact on job satisfaction and $\mathrm{p}=0.000>$ 0.05 and a coefficient amounted to 0.712 , this coefficient indicates that every teacher in carrying out teaching activities demonstrate competence and satisfied with the teaching profession that they do. SIM has a direct 
positive effect and no significant effect on job satisfaction and p-value $=0.089>0.05$ and a coefficient amounted to 0,139, this coefficient indicates that the SIM application still needs to be improved so that every teacher gets ease in teaching activities and are satisfied to run the activities of teaching in schools. Cultural organizations have direct influence positive and significant impact on job satisfaction and p-value $=0.010>0.05$ and a coefficient amounted to 0.412 , this coefficient indicates that teachers at each school run teaching activities appropriate prevailing organizational culture at the school and was satisfied the values espoused in the organization in order to teach.

Competence has a direct positive influence on organizational commitment and significant with p-value $=0.003>0.05$ and a coefficient amounted to 0.658 , this coefficient indicates that every teacher in carrying out teaching activities have demonstrated their competence and commitment to advancing the organization of teaching. SIM has a direct positive effect and no significant effect on job satisfaction and p-value $=0.165>0.05$ and a coefficient amounted to 0.157 , this coefficient indicates that the SIM application has been understood by every teacher who provides ease of teaching, but the teacher has not demonstrated its commitment to realize the goals of the organization in order to teach. Cultural organizations have direct positive influence on organizational commitment and significant with p-value $=0.022>0.05$ and a coefficient amounted to 0.428 , this coefficient indicates that each teacher has to understand the essence of the prevailing culture within the organization, thus demonstrating a commitment to comply with any provision of cultural values espoused in the organization of teaching.

Competence has a direct influence positive and significant impact on teacher performance with p-value $=0.000>0.05$ and a coefficient amounted to 0.694 , this coefficient indicates that every teacher in teaching demonstrate competence, which influenced the increase in performance. SIM has a direct positive effect and no significant effect on the performance of teachers by $p$-value $=0.185>0.05$ and a coefficient amounted to 0.161 ; this coefficient indicates that the SIM application has been implemented by each teacher, the actualization has not been able to improve the performance of teachers. Cultural organizations have direct influence positive and significant impact on teacher performance with $\mathrm{p}$-value $=0.000>0.05$ and a coefficient of 0.591 , this coefficient indicates that every teacher understands the importance of organizational culture implementation to run that give effect to an increase in performance.

Job satisfaction has a direct positive influence and significant impact on teacher performance with $\mathrm{p}$ value $=0.000>0.05$ and a coefficient amounted to 0.671 ; this coefficient indicates that the teacher had been satisfied with his profession as a teacher and it gives effect to the improved performance. Organizational commitment have direct influence positive and significant impact on teacher performance with p-value $=0.000$ > 0.05 and a coefficient amounted to 0.584; this coefficient indicates that the teacher has been committed to advancing the organization of teaching and it gives effect to the improved performance.

Competence through job satisfaction has a direct positive influence and significant impact on teacher performance coefficient indirect effect of 0.281 . Results of the calculations through Sobel test was obtained for $5.210>1.98$ with a significance level of $\mathrm{p}$-value $=0.000<0.05$, indirectly proves that every teacher in teaching demonstrate competence and satisfied with the profession as a teacher, which influenced the increase performance. SIM through job satisfaction have a positive indirect effect and no significant effect on the teacher's performance with coefficient indirect effect of 0.087. Results of the calculations through Sobel test was obtained for $0.490<1.98$ with a significance level of p-value $=0.624>0.05$, proving that indirectly IMS application has been run by each teacher gives job satisfaction in teaching, but the IMS application yet give effect to the improvement of teacher performance. Organizational culture through job satisfaction has a direct positive influence and significant impact on teacher performance coefficient indirect effect of 0.266 . Results of the calculations through Sobel test was obtained for 4729> 1.98 with a significance level of $\mathrm{p}$-value $=0.000$ $<0.05$, indirectly proves that the teacher showed satisfaction in performing organizational culture prevailing at each school, so as to give effect to increase performance.

Competence through organizational commitment has a direct positive influence and significant impact on teacher performance coefficient indirect effect of 0.281. Results of the calculations through Sobel test was obtained for 5.210 $>1.98$ with a significance level of $p$-value $=0.000<0.05$, indirectly proves that every teacher in teaching demonstrate competence and committed to the profession as a teacher, so as to give effect to increase performance. SIM through organizational commitment have a positive indirect effect and no significant effect on the teacher's performance with coefficient indirect effect of 0.087 . Results of the calculations through Sobel test was obtained for $0.490<1.98$ significance level of $\mathrm{p}$-value $=0.624>0.05$, proving that indirectly SIM application has been executed so far makes the teacher is committed to advancing the place of teaching, but the application of the SIM not give effect to increase teacher performance. Cultural organization through organizational commitment has a direct positive influence and significant impact on teacher performance coefficient indirect effect of 0.266 . Results of the calculations through Sobel test was obtained for 4729>1.98 with a significance level of $\mathrm{p}$-value $=0.000<0.05$, indirectly proves that the teachers in running the prevailing 
organizational culture at each school is committed to furthering the organization of teaching, which influenced the increase in teachers performance.

\section{Conclusion}

Based on the analysis and discussion of the results of research on the scope of Makassar City Department of Education, concluded as follows: (1) the competence of positive and significant impact on job satisfaction of teachers. Competency-based teacher pedagogical, professional, and social personality has a significant correlation to the respective indicators of job satisfaction; (2) driver's license and no significant positive effect on job satisfaction of teachers. The application of the IMS has been run by the teachers, but the IMS application did not show significant correlation to increased job satisfaction of teachers in the face of the challenges of work, work progress, achievement, creativity and work or the teaching profession itself; (3) organizational culture positive and significant impact on job satisfaction of teachers. Implementation of the organizational culture based on mission, consistency, adaptability and engagement showed a significant correlation to each indicator of job satisfaction; (4) the competence of positive and significant effect on organizational commitment of teachers.

All the indicators that build the competence of teachers showed a significant correlation to both affective organizational commitment, normative, continuous and perspectives; (5) IMS card and no significant positive effect on organizational commitment of teachers. IMS application of make teachers are able to access the information, apply and develop information technology Local area networks or internet (wifi) in the school, but this application is not directly related to the teachers' organizational commitment shown in implementing the teaching activities; (6) organizational culture positive and significant effect on organizational commitment of teachers. This means that all indicators of organizational culture show a significant correlation to organizational commitment of teachers based on affective commitment, normative, continuous and perspectives; (7) the competence of positive and significant impact on teacher performance.

The competence of teachers in the form of pedagogical, professional, personal and social indicate a significant correlation to the achievement of teacher performance achievement in the work of a series of teaching and learning process; (8) IMS card and no significant positive effect on the performance of teachers. IMS Application of every teacher is able to access the information, applying information technology and develop a network of local area network or internet (wifi) in the school, but the application is not directly related to teacher performance assessment standards must be improved; (9) organizational culture positive and significant impact on teacher performance. Means an organizational culture based on mission, consistency, adaptability and engagement showed a significant correlation to the achievement of performance based on teacher performance assessment standards; (10) of job satisfaction and a significant positive impact on teacher performance.

Each teacher showed his satisfaction that provides a real correlation to the performance of teachers in the planning / preparation of teaching, mastery of materials, methods and strategies of teaching, administration and management tasks as well as the assessment and evaluation of student learning; (11) organizational commitment and significant positive effect on the performance of teachers. Each teacher showed affective commitment, normative, continuous and perspective that gives a real correlation to the corresponding performance improvement attainable standard of teacher performance appraisal; (12) competence through job satisfaction and a significant positive impact on teacher performance. All indicators of the competency of teachers showed a significant correlation to the achievement of teacher job satisfaction and indirectly also provide real correlation to the improvement of teacher performance; (13) IMS through job satisfaction and no significant positive effect on the performance of teachers. Each teacher has understood the importance of a series of activities of input, process, output and feedback in a IMS application, but the application is not significantly correlated to job satisfaction, as the IMS application-oriented utilization and use of school media, and indirectly also not significantly correlated to the performance of teachers; (14) the culture of the organization through job satisfaction and a significant positive impact on teacher performance.

All indicators of organizational culture teacher showed a significant correlation to the perceived job satisfaction of teachers and indirectly also provide real correlation to the improvement of teacher performance; (15) competence through organizational commitment and significant positive effect on the performance of teachers. All indicators of the competency of teachers showed a significant correlation demonstrated organizational commitment of teachers and indirectly also provide real correlation to the improvement of teacher performance; (16) IMS through organizational commitment and no significant positive effect on the performance of teachers. Each teacher has understood the importance of a series of IMS applications, but its application was not significantly correlated to organizational commitment, because the IMS application-oriented utilization and use of school media, and indirectly also not significantly correlated to the performance of teachers; and (17) the culture of the organization through organizational commitment and significant positive effect on the performance of teachers. All indicators of organizational culture teacher showed a significant 
correlation demonstrated organizational commitment of teachers and indirectly also provide real correlation to the improvement of teacher performance.

\section{References}

[1]. Antonhy, Mark, (2011). Information Management in Theory and Practice. Prentice Hall, Ohio Press.

[2]. Beer, Keenoy \& Spector, Anthony (2004). Human Resource Management and Development. London, Sage.

[3]. Cholisin, Hamdani, (2006). Competence of Human Resources. Publisher Pustaka jaya, Jakarta.

[4]. Cleveland, Musk, (2008). Performance. Published by Harper T \& Row, New York.

[5]. Cushing, Wendell, (2009). Human Resource Management. Revision Edition, Hougton Mifflin Company, Boston.

[6]. Cushway, Cavaiola, (2001). Affect of Culture, Morality and Competence toward Increasing the Performance. http://www.publishingliterature.com.

[7]. Cushway, Cavaiola, (2007). Human resource quality as Human Resource Quality. Englewood Cliffs, NJ: Prentice Hall Inc.

[8]. Darmantyas, Harifuddin, (2007). Level Control In Achieving Purpose. Publisher Grassindo, Jakarta.

[9]. Dessler, Gary, (2009). Management of Human Resource. Published by Prentice Hall, New York.

[10]. Donald, McEachern, Thomas, (2008). Competence of Personal in Prospective Theories. http://www.journalhumanresourcemanagement.com.id.

[11]. Fiedler, George, (2008). Performance and Management. Published by Harper T \& Row, New York.

[12]. Follett, Marquett, (2004). Human Resource Management in the Quality and Quantity. http://humanresource.com.

[13]. Furtwengler, Dale (2004). Human Resource Management: Perspectives Prestation. http://humanresource.com.

[14]. Gibson, James L., (2007). Human Resource Management. Translation: Djarkasih, Fourth Edition, Erland, Jakarta.

[15]. Jogiyanto, (2010). Application Information Management System in the scope of the HR organization. Publisher Elex Media Komputindo, Jakarta.

[16]. Keith, John, (2007). Handbook of Human Resource Performance. McGraw-Hill, New York.

[17]. Mondy, R. Wayne \& Noe, Robert M., (2004). Human Resource Management, Alhyn \& Bacon.

[18]. Rival, Veithzal, (2004). Human Resource Management. Publisher Raja Grafindo Persada, Jakarta.

[19]. Sedarmayanti, (2008). Human Resource Management.PT. Refika Aditama, Bandung.

[20]. Terry, GR., (2008). Human Resource Management. Published by McGraw Hill, Ohio.

[21]. Wilson, Harry, (2007). Human Resource Management. $2^{\text {nd }}$ Edition, Hougton Mifflin Company, Boston.

Jayady Yahya. "Effect of Competence, Information Systems Management, Organizational Culture on the Job Satisfaction, Organizational Commitment and Teacher Performance ." IOSR Journal of Business and Management (IOSR-JBM), vol. 19, no. 10, 2017, pp. 91-100. 